ISSN 0103-5150

Fisioter. Mov., Curitiba, v. 29, n. 3, p. 461-467, Jul./Set. 2016

Licenciado sob uma Licença Creative Commons

DOI: http://dx.doi.org.10.1590/1980-5918.029.003.A003

(c) (i)

\title{
Correlation between movement of the feet and motor function of children with chronic encephalopathy
}

\author{
Correlação entre movimento dos pés e função \\ motora de crianças encefalopatas crônicas
}

\author{
Táubuta Gomes Souza ${ }^{[\mathrm{a}]}$, Elzo Pereira Pinto Junior ${ }^{[\mathrm{b}]}$, \\ Maria Nice Dutra de Oliveira ${ }^{[a]}$ Mirna Marques da Fonsêca ${ }^{[a]^{*}}$ \\ [a] Universidade Estadual do Sudoeste da Bahia (UESB), Jequié, Bahia, Brazil \\ [b] Universidade Federal da Bahia (UFBA), Salvador, Bahia, Brazil
}

\begin{abstract}
Introduction: Chronic non-progressive encephalopathy (CNPE) is one of the most common causes of physical deformities in childhood. It is characterized by non-progressive neuropathological abnormalities of the developing brain, which results in neuromotor impairments and changes in posture and movement. Objective: To evaluate foot deformities in children with CNPE, by measuring the joint amplitude and correlating these measures with the scores of the Gross Motor Function Measure (GMFM-88), using all its five dimensions. Methods: Cross-sectional and descriptive study with a sample of 17 children. The data collection instruments used were manual goniometer and the Gross Motor Function Measure test (GMFM-88). Data were analyzed using the program SPSS version 18, and the Pearson correlation test as a measure of association. Results: Children with chronic encephalopathy and a reduced amplitude motion have lower
\end{abstract}

*TGS: BS, e-mail: taubutagsouza@hotmaill.com EPPJ: Doctoral Student, e-mail: elzojr@hotmail.com MND0: MS, e-mail: mnicedutra@gmail.com MMF: BS, e-mail: mirna.mf@hotmail.com 
capacity in motor function. Statistically significant correlation was found for the right dorsiflexion angle ( $p=0.023)$, left dorsiflexion angle $(p=0.019)$, right inversion $(p=0.040)$, left inversion $(p=0.034)$ and left eversion ( $p=0.018)$. There was no statistically significant correlation for the right eversion ( $p>0.05)$. Conclusion: Musculoskeletal disorders associated with CNPE and foot deformities interfere negatively in motor function, compromising the functional performance of these children.

Keywords: Cerebral Palsy. Child. Foot Deformities.

\section{Resumo}

Introdução: A Encefalopatia Crônica não Progressiva da Infância (ECNPI) é uma das causas mais comuns de deformidades físicas na infância. É caracterizada por anormalidades neuropatológicas de caráter não progressivo do encéfalo em desenvolvimento, resultando em comprometimentos neuromotores e em alterações na postura e no movimento. Objetivo: avaliar as deformidades dos pés de crianças com ECNPI, através da mensuração da amplitude articular e correlacionar esses valores da mensuração com os escores do Gross Motor Function Measure (GMFM-88), utilizando todas as suas cinco dimensões. Métodos: Estudo transversal e descritivo realizado com uma amostra de 17 crianças. Os instrumentos de coleta de dados utilizados foram o goniômetro manual e o teste Gross Motor Function Measure (GMFM-88). As análises dos dados foram realizadas no programa SPSS v. 18, empregando-se o teste de correlação de Pearson como medida de associação. Resultados: Crianças encefalopatas crônicas com amplitude de movimento reduzida apresentam menor capacidade na função motora. Encontrou-se correlação estatisticamente significativa para os ângulos de dorsiflexão direita $(p=0,023)$, dorsiflexão esquerda $(p=0,019)$, inversão direita $(p=0,040)$, inversão esquerda $(p=0,034)$, para eversão esquerda $(p=0,018)$. Não houve correlação estatisticamente significativa para a variável eversão direita $(p>0,05)$. Conclusão: As alterações osteomusculares associadas à ECNPI, assim como as deformidades dos pés interferem negativamente na função motora, comprometendo o desempenho funcional dessas crianças.

Palavras-chave: Paralisia Cerebral. Criança. Deformidades do Pé.

\section{Introduction}

The term chronic non-progressive encephalopathy (CNPE) denotes a dissimilar number of clinical syndromes characterized by motor actions and abnormal postural mechanisms. These syndromes are caused by non-progressive neuropathological abnormalities of the immature brain (1). Chronic non-progressive encephalopathy is characterized as a disorder that causes postural and tonic deficits that compromise the execution of movements and hinders the child's relationship with the environment, causing secondary musculoskeletal changes. Thus, the child presents inability to maintain postures and perform normal movements (2).

In CNPE, brain injury leads to various neuromotor impairments, including musculoskeletal deformities of multifactorial etiology, especially in the lower limbs, the most frequent being the ankle equinus, the varus and valgus foot $(3,4)$. Most deformities tend to be progressive and debilitating, limiting the amount and variety of movements that depend on the motor control, the cognitive and the environment that surrounds the child $(5,6,7)$.
The CNPE is usually classified according to the type of tonus, lesion distribution in the body and level of independence $(8,9)$. Regarding tonus disorders, the most common is spasticity, with its incidence around $75 \%$, showing increased resistance to passive movement and exacerbation of tendon reflexes. Since spasticity is characteristic of some muscle groups and not others, it results in the appearance of joint deformities in this group of patients. The topographic classification of the lesion allows to sort the spastic children with unilateral or bilateral lesion.

The literature has recently demonstrated a preference to classify children with CNPE according to their gross motor function and functional performance $(10,11)$. For this purpose, there are standard scales commonly used to assess these children, such as the Gross Motor Function Measure - version 88 (GMFM88) which, when associated with the measurement of the joint amplitude through the manual goniometer, a widely used method in physical therapy practice, facilitate diagnosis, planning and a more effective therapeutic approach for these patients $(12,13,14)$. 
It is worth investigating evidence centered in the areas of functionality, evaluating the neuromusculoskeletal structures and functions compromised in CNPE, which includes observing the performance of these children in their daily routine and also their access and active participation. These areas together include internal and external parameters that influence the child's outcomes of functionality and disability $(2,3)$. However, few studies have mentioned the functional implications related to joint structural deformities in children with CNPE. These often interfere with acquisition of motor childhood skills, which are essential for the performance of activities and daily routine tasks.

In this context, the aim of this study was to evaluate foot deformities in children with CNPE, by measuring the joint amplitude and correlating these measurement values with the scores of the Gross Motor Function Measure (GMFM-88), using all its five dimensions.

\section{Methods}

A cross-sectional, descriptive and analytical study was developed with 17 children, of both sexes, affected by chronic non-progressive encephalopathy. The children who composed this sample received physical therapy at the Clinical Physical therapy School, at the Jequié Center of Prevention and Physical Rehabilitation and at the Association of Parents and Friends of Exceptional Children in the city of Jequié, in the Brazilian state of Bahia, and their characteristics for inclusion in the study were analyzed by the researchers through medical record review. The study included all children with a diagnosis of chronic non-progressive encephalopathy, the spastic type, over two years of age, with gait prognosis. Children with Lesch-Nyhan syndrome and $\backslash$ or quadriplegia, with no gait prognosis and who did not undergo continuous physical therapy treatment were excluded from the study.

Age, weight, height, topographic classification of CNPE and classification of the type of foot deformity of the study participants were the factors used to characterize the sample. As for the evaluation of gross motor function and measurement of joint mobility of the feet, the GMFM-88 scale and a manual goniometer were used, respectively. Other clinical information was collected through interviews with officials and consultation of hospital records.
The GMFM-88 scale consists of 88 items grouped into five dimensions or sub-scales: A- lying and rolling; B- sitting; C- crawling and kneeling; D-standing; E- walking, running and jumping. The items in each dimension are scored on a four-point scale, ranging from zero to three. This study used all dimensions of the GMFM (15).

Feet angles were measured using the "FUTURA" goniometer, consisting of a full circle $\left(0^{\circ}\right.$ to $\left.360^{\circ}\right)$ made of plastic, with two arms, one fixed and one movable. The angles were assessed in four joint movements: A- dorsiflexion; B- plantar flexion; Cinversion; D- eversion. Three measurements for each angle were recorded, and for statistical purposes the intermediate value between the three measures was used (16). These measurements were performed on both members.

The children included in the study were evaluated in the physical therapy clinics of the three participating centers, during March and April 2014. Each participant was assessed only once. First, the examiner applied the GMFM-88, having previously collected the other clinical information. The next step was to measure the foot range of motion. Arthrometry was performed with the subject in a sitting position. Dorsiflexion was the first joint movement to be measured, positioning the drive shaft in the foot side edge, below the lateral malleolus, the fixed arm parallel to the longitudinal axis of the fibula and the movable arm parallel to the lateral border of the foot, toward the fifth metatarsus. Plantar flexion was then measured, with the drive shaft on the leg side edge, below the lateral malleolus, fixed arm parallel to the longitudinal axis of the fibula and the parallel movable arm walking from side edge toward the fifth metatarsus. The third joint movement to be measured was the inversion, with the drive shaft on the anterior side of the tibial-tarsal articulation, the fixed arm parallel to the longitudinal axis of the tibia and the movable arm on the dorsal surface of the foot toward the second metatarsus. Finally, eversion was measured with the drive shaft on the anterior side of the tibial-tarsal articulation, the fixed arm parallel to the longitudinal axis of the tibia and the movable arm on the dorsal surface of the foot toward the third metatarsus.

The collected data were tabulated in a Microsoft Excel spreadsheet and then converted to the statistical analysis software Statistical Package for the Social Sciences (SPSS) version 18.0. The outcome variable was the total score of the GMFM 
scale and the main independent variables were the passive range of motion of the angles of the feet, whose descriptive analysis was performed using its mean and standard deviation (SD). Other variables such as age, weight, height, topographic classification of cerebral palsy and the classification of foot type were treated based on the analysis of absolute and relative frequencies and on measures of central tendency (mean) and dispersion (standard deviation). The normal distribution of the data was tested and confirmed by the Shapiro-Wilk test. Pearson's correlation test was used to assess the association between the outcome and the variables related to the range of motion, being considered a statistically significant association if $\mathrm{p}$-value $<0.05$.

Data from this study are part of the project "Repercussões funcionais associadas às deformidades dos pés em crianças com Encefalopatia Crônica", which was approved by the Research Ethics Committee of the Universidade Estadual do Sudoeste da Bahia (protocol no. 613 380). All legal guardians of the participants signed a Free and Informed Consent Form authorizing the children's participation, according to the ethical principles of Resolution 466/2012 of the National Health Council.

\section{Results}

The population studied had a mean age of 9.5 years ( $\mathrm{SD} \pm 3.92$ ), mean body mass of $32.7 \mathrm{~kg}$ ( $S D \pm 15.46)$ and mean height of $132.2 \mathrm{~cm}(\mathrm{SD} \pm 9.90)$. Regarding the topographical classification, most of the individuals presented bilateral lesions (52.9\%). In the classification of the foot type, the equinus was the most common (52.9\%) (Table 1).

Table 2 presents the main descriptive measures of the arthrometric values of the passive range of motion of the children's feet, and the p-value of the Pearson correlation, to which the sample was submitted. According to Pearson's correlation test, there is a statistically significant correlation between the score in the motor performance scale GMFM-88 and the foot range of motion in most of the evaluated angles, except on the relationship between functionality and right eversion $(p=0.074)$.

Table 2 also shows that the decrease of the angle in the left $(\mathrm{p}=0.010)$ and right plantar flexion $(p=0.011)$ has a higher statistically significant relationship to loss of functionality. The angles of the feet evaluated in the left side of the body showed a higher relationship to loss of functionality than the ones evaluated in the right side.

Table 1 - Anthropometric variables, type of neurological damage and classification of foot deformities in children with chronic non-progressive encephalopathy, Jequié, Bahia, Brazil, 2014

\begin{tabular}{|c|c|c|c|}
\hline & Mean $( \pm S D)$ & $\mathrm{n}$ & $\%$ \\
\hline $\begin{array}{c}\text { Anthropometric } \\
\text { variables }\end{array}$ & & & \\
\hline Age (years) & $9.52( \pm 3.92)$ & - & - \\
\hline Body mass (Kg) & $32.76( \pm 15.46)$ & - & - \\
\hline Height (cm) & $132.29( \pm 19.90)$ & - & - \\
\hline $\begin{array}{l}\text { Topographic } \\
\text { classification }\end{array}$ & & & \\
\hline Bilateral & - & 9 & 52.9 \\
\hline Unilateral & - & 8 & 47.1 \\
\hline $\begin{array}{l}\text { Classification } \\
\text { of the foot } \\
\text { deformities }\end{array}$ & & & \\
\hline Calcaneal varus & - & 6 & 35.3 \\
\hline Calcaneal valgus & - & 2 & 11.8 \\
\hline Equinus & - & 9 & 52.9 \\
\hline
\end{tabular}


Table 2 - Foot range of motion and correlation with the total score of the GMFM-88 scale in children with chronic nonprogressive encephalopathy, Jequié, Bahia, Brazil, 2014

\begin{tabular}{|c|c|c|c|c|c|}
\hline \multirow{2}{*}{$\begin{array}{l}\text { Feet angle } \\
(\mathrm{N}=17)\end{array}$} & \multirow[t]{2}{*}{ Mean $\left(^{\circ}\right)$} & \multirow[t]{2}{*}{ Minimum $\left({ }^{\circ}\right)$} & \multirow[t]{2}{*}{ Maximum $\left({ }^{\circ}\right)$} & \multicolumn{2}{|c|}{$\begin{array}{c}\text { GMFM-88 } \\
\text { Score correlation }\end{array}$} \\
\hline & & & & $R$ value & $P$ value \\
\hline RD & $8.47 \pm 4.97$ & 0 & 20 & 0.549 & $0.023^{*}$ \\
\hline LD & $6.58 \pm 5.23$ & 0 & 20 & 0.563 & $0.019^{*}$ \\
\hline RP & $28.05 \pm 13.28$ & 0 & 50 & 0.601 & $0.011^{*}$ \\
\hline LP & $24.17 \pm 16.30$ & 0 & 51 & 0.609 & $0.010^{\star}$ \\
\hline RI & $24.17 \pm 8.75$ & 0 & 41 & 0.501 & $0.040^{*}$ \\
\hline LI & $24.29 \pm 8.47$ & 0 & 43 & 0.517 & $0.034^{*}$ \\
\hline RE & $13.05 \pm 5.08$ & 0 & 20 & 0.444 & 0.074 \\
\hline LE & $12.05 \pm 5.17$ & 0 & 20 & 0.567 & $0.018^{*}$ \\
\hline
\end{tabular}

Note: Pearson's Test $\left.{ }^{*}\right) p<0,05$; (RD) Right dorsiflexion; (LD) Left dorsiflexion; (RP) Right plantar flexion; (LP) Left plantar flexion; (RI) Right inversion; (LI) Left inversion; (RE) Right eversion; (LE) Left eversion; (GMFM) Gross Motor Function Measure. Source: research data.

\section{Discussion}

In this study, the most common type of foot deformity was the equinus, coinciding with results of studies by Fucs et al. (17), which results in a smaller amplitude for the plantiflexion of the ankle in children with CNPE when compared to normal kids. The loss of the plantar flexion movement of the feet interferes with walking activities, transferring from a sitting position to a standing position and with the maintenance of an upright posture (18). Similarly, the results of this study show that the decrease in these plantar flexion movements on the lower right limbs and especially in the lower left limbs showed higher correlation with functional loss of the children analyzed through the total score of the GMFM-88 scale.

The foot range of motion is governed by the muscles, both extrinsic and intrinsic. The extrinsic muscles are originated below the knee and their insertion goes to the bottom of the foot. They are responsible for plantar flexion, dorsiflexion, inversion and eversion, and also for the movement of the toes. The intrinsic muscles originate below the ankle joint, are inserted in the plant or instep, and perform the function of moving the toes $(19,20)$. Children with CNPE, in their majority, have impairments in intrinsic and extrinsic muscles of the feet, such as shortenings, which result in restricted amplitude of these movements and consequent loss of functionality (21).
Children with CNPE have difficulties maintaining a proper posture and they often keep incorrect body positions, especially related to joints such as ankles and feet, which support the body weight. The consequences are muscle shortening and the onset of structural deformities in these patients (22). These changes and deformities can be progressive even during physical therapy $(23,24)$. As the child with CNPE becomes more active, postures and movement disorders are developed, causing neuromusculoskeletal impairments and limitations in functional performance $(25,26)$.

Given the findings of this study, the influence of foot deformities in the functional deficit of children with CNPE was observed, revealing the close relationship between these variables. Children with major joint deformities have severe motor dysfunction and less independence to perform functional skills $(27,28,29)$. This relationship is extremely important for evidencing that a greater joint mobility of the ankle and toes, associated with a lower level of neuromotor impairment, enables greater functional performance $(30,31)$. Therefore, as one of the major goals of physical therapy is functional gain, the influence of comorbidities should not be underestimated, such as foot deformities associated with functional loss in children with CNPE and its impact on daily activities $(32,33)$.

In the literature, it is evident that hemiplegic children with CNPE are prone to the development of postural imbalances and to the asymmetric compromise of structures such as feet and ankles $(3,8,18)$. 
However, in this study, asymmetric patterns were observed even in children with bilateral involvement, with predominance of the functional implications in those who had more severe deformities in their left foot, which suggests further biomechanical studies to explore the reasons for these disparities.

Evidences in the literature show that the lower the functional performance of children with CNPE, the greater the impairment in gross motor function (34), as indeed was observed in this study. There is a correlation between the limitations in the ankle range of motion, due to the presence of foot deformities, with a smaller capacity of gross motor function. In other words, the greater the impairment of this joint, the lower the mobility and functional performance of these children.

\section{Conclusion}

This study revealed that foot deformities in children with CNPE compromise the functional performance and that the arthrometric assessment along with the GMFM-88 functional scale ratings are good indicators to evaluate these children. It is also relevant to understand how these instruments relate to the gross motor functions, reflecting on their limitations to carrying out activities and their functional performance. However, studies with larger sample sizes are needed in order to get to deeper conclusions.

Studies of biomechanical analysis like this provide useful data to guide the therapeutic practice, helping plan the most effective form of intervention for patients in order to develop their potentialities.

\section{References}

1. Miller G. Paralisia Cerebral: Uma Visão Geral. In: Miller G, Clark GD. Paralisias Cerebrais - causas, consequências e conduta. Barueri: Manole; 2002. p. 3-9

2. Araújo RCT. A formação conceitual na paralisia cerebral: busca de uma explicação segundo a concepção epistemológica de Jean Piaget. Cadernos da FFC. 1999;8(1): 55-77.

3. Ferrareto I. Paralisia Cerebral. In: Souza AMC, Ferraretto I. Paralisia Cerebral - Aspectos práticos. 2nd ed. São Paulo: Frontis Editorial; 2001. p. 63-105.
4. Duffy CM, Cosgrove AP. The foot in cerebral palsy. Curr Ortho. 2002;16:104-13.

5. Levitt S. O tratamento da paralisia cerebral e do retardo motor. 3rd ed. Barueri (Brazil): Manole; 2001. Portuguese.

6. Behrman RM, Kliegman R, Arvin A. Tratado de pediatria. 15th ed. Rio de Janeiro: Guanabara Koogan; 2002. Portuguese.

7. Lopes GHR, David AC. Posturografia na análise do equilíbrio em crianças com paralisia cerebral: Uma revisão de literatura. Fisioter Pesq. 2013;20(1):97-102.

8. Gauzzi LDV, Fonseca LF. Classificação da paralisia cerebral. In: Lima CLA, Fonseca LF. Paralisia cerebral: neurologia, ortopedia, reabilitação. Rio de Janeiro: Guanabara-Koogan; 2004. p. 37-44. Portuguese.

9. Palmer LM, Epler ME. Tornozelo e Pé: In: Palmer LM, Epler ME. Fundamentos das Técnicas de Avaliação Musculoesquelética. 2nd ed. Rio de Janeiro: Guanabara Koogan; 2000. p.302-36. Portuguese.

10. Cury VCR, Mancini MC, Melo AP, Fonseca ST, Sampaio RF, Tirado MGA. Efeitos do uso de órtese na mobilidade funcional de crianças com paralisia cerebral. Rev Bras Fisioter. 2006;10(1):67-74.

11. Sacco ICN, Alibert S, Queiroz BWC, Pripas D, Kieling I, Kimura AA, Selmerr AE. Confiabilidade da fotogrametria em relação à goniometria para avaliação postural de membros inferiores. Rev Bras Fisioter. 2007;11(5):411-7.

12. Avery LM, Russell DJ, Raina PS, Walter SD, Rosenbaum PL. Rasch analysis of the Gross Motor Function Measure: validating the assumptions of the Rasch model to create an interval-level measure. Arch Phys Med Rehabil. 2003;84:697-705.

13. Edwards S. Fisioterapia neurológica: uma abordagem centrada na resolução de problemas. Porto Alegre (Brazil): Artes Médicas; 2006. Portuguese.

14. Zonta MB, Ramalho Júnior A, Santos LHC. Avaliação funcional na Paralisia Cerebral. Acta Pediatr Port. 2011;42(1):27-32.

15. Nunes LCBG. Tradução e Validação de instrumentos de avaliação motora e de qualidade de vida em paralisia cerebral [tese]. Campinas (Brazil): Universidade Estadual de Campinas; 2008. Portuguese.

16. Souza AK, Moreira D, Santana LA. Manual fotográfico de goniometria e fleximetria incluindo testes de retração muscular. 2nd ed. Brasília: Thesaurus; 2010. Portuguese. 
17. Fucs PMMB, Assumpção RMC, Svartman C. Tratamento cirúrgico do pé eqüino na paralisia cerebral: Uma revisão sistemática e quantitativa da literatua. Rev Bras Ortop. 2008;43(9):388-98.

18. Borges MBS, Silveira JA, Jerônimo BP, Dini PD, David AC. Variáveis espaço-temporais da marcha de crianças com paralisia cerebral submetidas a eletroestimulação do músculo tibial-anterior. Rev Bras Fisioter. 2007;11(4):261-6.

19. Pato TR, Souza DR, Leite HP. Epidemiologia da paralisia cerebral. Acta Fisiatr. 2001;8(1):18-23.

20. Magee DJ. Perna, Tornozelo e Pé In: Magee DJ. Disfunção Musculoesquelética. 3rd ed. Barueri (Brazil): Manole; 2002. p. 621-95. Portuguese.

21. van der Heide JC, Hadders-Algra M. Postural muscle dyscoordination in children with cerebral palsy. Neural Plast. 2005;12(2-3):197-203.

22. Ferreira AS, Gave NS, Abrahão F, Silva JG. Influência da morfologia de pés e joelhos no equilíbrio durante o apoio bipodal. Fisioter Mov. 2010;23(2):193-200.

23. Rotta NT. Paralisia cerebral, novas perspectivas fisioterapêuticas. J Pediatr. 2002;78(Supl.1):S48-S54.

24. Schwartzman JS. Paralisia cerebral. Arq Bras Paralisia Cerebral. 2004;1(1):4-17.

25. Costa TDA, Carvalho SMR, Bracialli LMP. Análise do equilíbrio estático e de deformidades nos pés de crianças com paralisia cerebral. Fisioter Pesq. 2011;18(2):127-32.

26. Marques JS, Fernandes PR, Fernandes Filho J, Policarpo LB. Maturação da marcha em crianças com paralisia cerebral: um estudo piloto. Motricidade. 2011;7(2):39-46.

27. Mancini MC. Inventário de Avaliação Pediátrica de Incapacidade (PEDI): manual da versão brasileira. Belo Horizonte (Brazil): UFMG; 2005. Portuguese.

28. Mancini MC, Defilipo EC, Lemos RA, Chagas PSC, Frônio JS, Carvalho RM. Classificação da função motora e do desempenho funcional da criança com paralisia cerebral. Rev Bras Fisioter. 2008;12(5):409-16.

29. Mancini MC. Comparação do desempenho de atividades funcionais em crianças com desenvolvimento normal e crianças com paralisia cerebral. Arq Neuro-Psiquiatr. 2002;60(2):446-52.
30. Campos TF, Vasconcelos RLM, Moura TL, Lindquist ARR, Guerra RO. Avaliação do desempenho funcional de crianças com paralisia cerebral de acordo com níveis de comprometimento motor. Rev Bras Fisioter. 2009;13(5):390-7.

31. Zonta MB, Júnior AR, Camargo RMR, Dias FH, Santos LHC. Two-dimensional analysis of gait asymmetry in spastic hemiplegia. Einstein (Sao Paulo). 2010;8(3):343-9

32. Filippin NT, Bonamigo ECB. Implicações Terapêuticas da Análise Dinâmica da Marcha na Paralisia Cerebral Diplégica - Um Estudo de Caso. Praxisterapia. 2003;8(8):25-35.

33. Gabriel APT, Stein HE, Machado Neto L. Tratamento do Pé Varo Espástico Através da Hemitransposição do Tendão do Tibial Anterior. Acta Ortop Bras. 2004;12(4):205-11.

34. Hebert S, Barros TEP. Ortopedia e traumatologia: Princípios e práticas. 4th ed. Porto Alegre (Brazil): Artmed; 2009. Portuguese.

Received in 09/08/2014

Recebido em 08/09/2014

Approved in 10/15/2015 Aprovado em 15/10/2015 
